\title{
CDH17 wt Allele
}

National Cancer Institute

\section{Source}

National Cancer Institute. CDH17 wt Allele. NCI Thesaurus. Code C143097.

Human CDH17 wild-type allele is located in the vicinity of $8 \mathrm{q} 22.1$ and is approximately 90 $\mathrm{kb}$ in length. This allele, which encodes cadherin-17 protein, plays a role in cell-cell adhesion and peptide transport. Mutations in the gene may be associated with melanoma. 